\title{
SYNTHESIS OF TETRAKIS-N,N,N-TRIMETHYLAMMONIUMMETHYL-C-3,4- DIMETHOXYPHENYLCALIX[4]RESORCINARENE IODIDE BASED VANILLIN AND ITS ANTIDOTE ACTIVITY FOR CHROMIUM(VI) INTOXICATION
}

\author{
Suryadi Budi Utomo ${ }^{1, *}$, Jumina $^{2}$, Dwi Siswanta ${ }^{2}$, and Mustofa ${ }^{3}$ \\ ${ }^{1}$ Chemical Education Study Program, PMIPA FKIP, Sebelas Maret University, Surakarta \\ ${ }^{2}$ Department of Chemistry, Faculty of Mathematics and Natural Sciences, Universitas Gadjah Mada, \\ Jl. Sekip Utara, Yogyakarta 55281 \\ ${ }^{3}$ Department of Pharmacology and Toxicology, Faculty of Medicine, Universitas Gadjah Mada, Yogyakarta 55281
}

Received January 18, 2013; Accepted May 23, 2013

\begin{abstract}
A research has been conducted to synthesize tetrakis- $N, N, N$-trimethylammoniummethyl-C-3,4dimethoxyphenylcalix[4]resorcinarene iodide from vanillin and investigate its antidote capability for $\operatorname{Cr}(\mathrm{VI})$ intoxication. The synthesis was carried out in four steps i.e. (1) O-alkylation of 4-hydroxy-3-methoxybenzaldehyde, (2) HCl-catalyzed condensation of 3,4-dimethoxybenzaldehyde with resorcinol, (3) Mannich reaction of C-3,4-dimethoxyphenylcalix[4]resorcinarene with formaldehyde and dimethylamine in the presence of $\mathrm{HCl}$ to yield tetrakis-N,N-dimethylaminomethyl-C-3,4-dimethoxyphenylcalix[4]resorcinarene, and (4) treatment the Mannich base with methyl iodide to produce the quaternary ammonium salt of tetrakis- $\mathrm{N}, \mathrm{N}, \mathrm{N}$-trimethylammoniummethyl-C-3,4dimethoxyphenylcalix[4]resorcinarene iodide. According to the analysis of ${ }^{1} \mathrm{H}-\mathrm{NMR}$ spectrometer, the targeted compounds tend to exist in the chair $\left(C_{2 h}\right)$ conformation. The capability of resorcinarene for $\mathrm{Cr}(\mathrm{VI})$ antidote was examined by orally injection method on mice groups. Based on $L D_{50}$ determination, the resorcinarene was classified as non toxic compound according to Loomis criteria. Therapeutic using quaternary ammonium-modified resorcinarene was able to reduce metal concentrations of $\mathrm{Cr}(\mathrm{VI})$ in liver, kidney, and serum in the magnitude of 78.30; 85.72, and 88.79\%, respectively. The higher dose of drug administered the greater decrease in the level of heavy metal. Judging from the amount of milligrams of reduced chromium per gram of organ, kidney is the organ having highest decreasing metal concentrations.
\end{abstract}

Keywords: vanillin; tetrakis-N,N,N-trimethylammoniummethyl-C-3,4-dimethoxyphenyl-calix[4]resorcinarene iodide; $L D_{50}$; antidote; $\mathrm{Cr}(\mathrm{VI})$

\begin{abstract}
ABSTRAK
Telah dilakukan penelitian untuk mensintesis tetrakis- $N, N, N$-trimetilammoniummetil-C-3,4dimetoksifenilkaliks[4]resorsinarena iodida dari vanilin dan menyelidiki kemampuannya sebagai antidotum keracunan $\mathrm{Cr}(\mathrm{VI})$. Sintesis dilakukan dalam empat tahap yaitu (1) O-alkilasi 4-hidroksi-3-metoksibenzaldehida, (2) kondensasi 3,4-dimetoksibenzaldehida dengan resorsinol terkatalisis $\mathrm{HCl}$, (3) reaksi Mannich C-3,4-dimetoksifenilkaliks[4]resorsinarena dengan formaldehida dan dimetilamina dengan adanya $\mathrm{HCl}$ untuk menghasilkan tetrakis- $\mathrm{N}, \mathrm{N}$-dimetilaminometil-C-3,4-dimetoksifenilkaliks[4]resorsinarena, dan (4) reaksi basa Mannich dengan metil iodida untuk menghasilkan garam amonium kuartener tetrakis- $N, N, N$-trimetilammoniummetilC-3,4-dimetoksifenilkaliks[4]resorsinarena iodida. Berdasarkan analisis ${ }^{1} \mathrm{H}-\mathrm{NMR}$, senyawa target berada dalam konformasi kursi $\left(\mathrm{C}_{2 h}\right)$. Kemampuan resorsinarena sebagai antidotum $\mathrm{Cr}(\mathrm{VI})$ diuji dengan metode injeksi secara oral pada mencit putih. Berdasarkan penentuan $L D_{50}$, resorsinarena uji diklasifikasikan sebagai senyawa non toksik menurut kriteria Loomis. Pemberian resorsinarena termodifikasi ammonium kuartener mampu mengurangi konsentrasi logam $\mathrm{Cr}(\mathrm{VI})$ dalam organ hati, ginjal dan serum secara berturut-turut hingga 78,30; 85,72 dan 88,79\%. Semakin tinggi dosis obat yang diberikan maka semakin besar penurunan kadar logam berat tersebut. Ditinjau dari besaran miligram kromium terkurangi setiap gram organ maka ginjal merupakan organ yang paling banyak mengalami penurunan konsentrasi logam.
\end{abstract}

Kata Kunci: vanilin; tetrakis-N,N,N-trimetilammoniummetil-C-3,4-dimetoksifenilkaliks[4]-resorsinarena iodida; $L D_{50}$; antidotum; $\mathrm{Cr}(\mathrm{VI})$

${ }^{*}$ Corresponding author. Tel/Fax : +62- 271-648939

Email address : sbukim98@yahoo.com

Suryadi Budi Utomo et al. 


\section{INTRODUCTION}

The macrocyclic molecules of resorcinarenes are cyclic tetramers easily available via one-step reaction by acid-catalyzed condensation of resorcinol and various aldehydes [1-5]. Investigation by in vitro method, these compounds have been studied with regard to inclusion of cations [2,6-9], anions [10-11], and organic neutral molecules [3-4,12,]. Recently, Henge-Napoli et al. [13] proved that the Calix[4]arenas containing sulphonato group is an effective antidote on reducing the heavy metal concentration in vivo tests on mice. The results of these experiments are consistent with the discovery of Shinkai et al. [14] who reported that the $p$-sulphonatocalix[6]arene shows much greater selectivity towards uranium than $\mathrm{Zn}^{2+}, \mathrm{Ca}^{2+}$, and $\mathrm{Cr}^{3+}$. Calixarene compounds also play important role in medicine and treatment, for example are 4-sulphonatocalix[4]arene and 4-sulphonato-calix[6]arene. Both of them together with cyclodextrins increase the solubility of niclosamide in water. Thus the drug will be more quickly absorbed into the corresponding receptors in the body so it will feel the effects of drug soon [15].

Meanwhile, the presence of heavy metals in environment has been increased due to the industrial activities [16-18]. It leads to bioaccumulation of the metals in living organism, causing health problems in animals, plants, and human being [19]. In humans and animals, trivalent chromium is an essential nutrient that plays an important role in glucose, fat and protein metabolism. In contrast, products which contain a hexavalent chromium base are oxidising agents capable of inducing tissue damage leading to conditions such as dermatitis [20], lymphocyte apoptosis [21], nefrotoxity [22-23] and hepatotoxity [24], in addition to contributing to the potential carcinogenic, teratogenic and mutagenic risk [25].

Therefore, based on the phenomena above, we recently become interested in exploring the synthesis of calix[4]resorcinarene derivatives that has capability in binding guest of heavy metal anion of $\mathrm{Cr}(\mathrm{VI})$. In this work, we report the synthesis of quaternary ammonium modified of calix[4]resorcinarene using vanillin as starting material. Here in, we also investigate the usage of the synthesized compound as antidote for acute $\mathrm{Cr}(\mathrm{VI})$ intoxication through in vivo examination.

\section{EXPERIMENTAL SECTION}

\section{Materials}

Vanillin, dimethyl sulfate, sodium hydroxide, resorcinol, absolute ethanol, fuming hydrochloric acid, dimethylamine, formaldehyde, acetone, methyl iodide, carboxymethyl cellulose, and potassium dichromate. All reagents in analytical grade were obtained from $E$ Merck Co Inc. (Germany) and used without further purification. The specimens (mice Balb/c) were obtained from Pharmacology and Toxicology Laboratory, Medicine Faculty of Universitas Gadjah Mada, Yogyakarta.

\section{Instrumentation}

Instruments used in this study were melting point electro thermal 9100, TLC (silica gel 7730 60GF 254 ), Shimadzu FTIR-Prestige-21, JEOL-MY500 NMR $\left({ }^{1} \mathrm{H}\right.$ at $500 \mathrm{MHz},{ }^{13} \mathrm{C}$ at $\left.125 \mathrm{MHz}\right)$, Bruker AC300F NMR ( ${ }^{1} \mathrm{H}$ at $300 \mathrm{MHz},{ }^{13} \mathrm{C}$ at $75 \mathrm{MHz}$ ), and Shimadzu AAS AA6650-F.

\section{Procedure}

\section{O-alkylation of vanillin}

3,4-Dimethoxybenzaldehyde (veratraldehyde) was made from vanillin via O-alkylation with dimethylsuphate according to the previous procedure [26].

\section{Synthesis of C-3,4-dimethoxyphenylcalix[4]resorcin arene (1)}

The mixture of resorcinol $(0.55 \mathrm{~g} ; 5 \mathrm{mmol})$, vanillin $(5 \mathrm{mmol})$, absolute ethanol $(50 \mathrm{~mL})$, and hydrochloride acid fuming $(0.5 \mathrm{~mL})$ was stirred under reflux at $80^{\circ} \mathrm{C}$ for $24 \mathrm{~h}$ until the reactants used up at the reaction (TLC monitoring). Furthermore, the mixture was cooled and the product was filtered followed by washing with ethanol-aquadest $(1: 1)$ then dried to give the desired compound 1 as a white-orange crystal in $97.54 \%$, 346-348 ${ }^{\circ} \mathrm{C}$; FTIR (KBr) $v\left(\mathrm{~cm}^{-1}\right): 3402(\mathrm{OH})$, $3024\left(\mathrm{C}_{\mathrm{sp} 2}-\mathrm{H}\right), 1604$ and $1512(\mathrm{C}=\mathrm{C}$ aromatic), 3000-2846 ( $\mathrm{C}_{\mathrm{sp} 3}-\mathrm{H}$ aliphatic), $1427 \quad(-\mathrm{CH}$ methine bridge), $1373\left(-\mathrm{CH}_{3}\right) ;{ }^{1} \mathrm{H}-\mathrm{NMR}\left(500 \mathrm{MHz}, \mathrm{DMSO}-d_{6}\right)$ $\delta$ (ppm): $8.29(8 \mathrm{H}, s, \mathrm{OH}), \quad 6.41-6.46 \quad(2 \mathrm{HH}, m, \mathrm{ArH})$, $5.68\left(4 \mathrm{H}, s, \mathrm{Ar}_{2} \mathrm{CHAr}\right.$ ) (in acetone- $d_{6}$ the signal of this chemical shift give multiple peaks), 3.69 and 3.44 $\left(24 \mathrm{H}, \mathrm{s}, \mathrm{OCH}_{3}\right) ;{ }^{13} \mathrm{C}-\mathrm{NMR}\left(125 \mathrm{MHz}\right.$, DMSO- $\left.d_{6}\right) \delta(\mathrm{ppm})$ : 152.9 (- $\mathrm{C}-\mathrm{OH}), 152.7$ (- $-\mathrm{C}-\mathrm{OMe}), 143.7,137.0,120.9$, $120.7,114.1,112.7,102.1(\mathrm{Ar}), 55.0\left(\mathrm{OCH}_{3}\right), \quad 40.6$ $\left(\mathrm{Ar}_{2} \underline{\mathrm{C}} \mathrm{HAr}\right)$.

\section{Synthesis of tetrakis- $\mathrm{N}, \mathrm{N}$-dimethyl-aminomethyl-C- 3,4-dimethoxyphenylcalix [4]resorcinarene (2)}

C-3,4-Dimethoxyphenylcalix[4]resorcinarene $(0.5$ $\mathrm{mmol}$ ) was dissolved in $30 \mathrm{~mL}$ of acetone. To a stirred of this mixture was added $0.186 \mathrm{~mL}(2.5 \mathrm{mmol})$ of formaldehyde $37 \%, \quad 0.316 \mathrm{~mL} \quad(2.5 \mathrm{mmol})$ of dimethylamine, and $1 \mathrm{~mL}$ of $\mathrm{HCl}$ respectively. The mixture was stirred at room temperature for $48 \mathrm{~h}$ until the reactants used up at the reaction (TLC monitoring). 
Solvent was removed by evaporation under reduced pressure. The residue was triturated with methanol: water (1:1). The precipitate was then filtered, washed several times with methanol, and dried to give the title compound $2(0.912 \mathrm{~g}, 72.40 \%)$ as brown crystal; m.p. 378-380 ${ }^{\circ} \mathrm{C}$; FTIR $(\mathrm{KBr}) v\left(\mathrm{~cm}^{-1}\right): 3410(\mathrm{OH}), 1604$ and 1512 ( $\mathrm{C}=\mathrm{C}$ aromatic), 3000-2785 ( $\mathrm{C}_{\mathrm{sp} 3}-\mathrm{H}$ aliphatic), 1465 $\left(-\mathrm{CH}_{2}-\right), 1373\left(-\mathrm{CH}_{3}\right) ;{ }^{1} \mathrm{H}-\mathrm{NMR}\left(500 \mathrm{MHz}, \mathrm{DMSO}-\mathrm{d}_{6}\right) \delta$ (ppm): $8.26(8 \mathrm{H}, \mathrm{d}, \mathrm{OH}), \quad 6.21-6.47(16 \mathrm{H}, \mathrm{m}, \mathrm{ArH}), \quad 5.64$ $\left(4 \mathrm{H}, \mathrm{d}, \mathrm{Ar}_{2} \mathrm{CHAr}\right), \quad 4.51-4.70 \quad\left(8 \mathrm{H}, \mathrm{m}, \mathrm{ArCH}_{2} \mathrm{~N}-\right), \quad 3.68$ $\left(24 \mathrm{H}, \mathrm{d}, \mathrm{OCH}_{3}\right), 3.45\left(24 \mathrm{H}, \mathrm{s}, \mathrm{NMe}_{2}\right) ;{ }^{13} \mathrm{C}-\mathrm{NMR}(75 \mathrm{MHz}$, DMSO-d $\left._{6}\right) \delta(\mathrm{ppm}): 152.8$ (- $\left.-\mathrm{C}-\mathrm{OH}\right), 152.6(-\underline{\mathrm{C}}-\mathrm{OH}), 148.5$ (-C-OMe), 146.5 (-C-OMe), 135.0, 130.5, 124.9, 124.5, 121.8, 113.1, 109.3, 108.7 (Ar), $54.9\left(\mathrm{OCH}_{3}\right), 47.2$ $\left(\mathrm{NMe}_{2}\right), 46.8\left(\mathrm{Ar}-\underline{\mathrm{C}} \mathrm{H}_{2}-\mathrm{NMe}_{2}\right), 31.1$ ( $\left.\mathrm{Ar}_{2} \underline{\mathrm{C}} \mathrm{HAr}\right)$.

\section{Synthesis of tetrakis-N,N,N-trimethyl-ammonium methyl-C-3,4-dimethoxyphenyl-calix[4]resorcinarene iodide (3)}

To a stirred solution of tetrakis-N,Ndimethylaminomethyl-C-3,4-dimethoxyphenylcalix[4]

resorcinarene $(1.0 \mathrm{mmol})$ in $30 \mathrm{~mL}$ acetone was added methyl iodide $(5.0 \mathrm{mmol})$ drop wise. The mixture was then stirred and refluxed for $2 \mathrm{~h}$. The solvent was removed by evaporation under reduced pressure to leave a red-brick residue, washed several times with water-methanol (1:1) and dried to yield $0.912 \mathrm{~g}$ of product 3 (90.25\%); m.p. $334-335{ }^{\circ} \mathrm{C}$; FTIR ( $\left.\mathrm{KBr}\right)$ $v\left(\mathrm{~cm}^{-1}\right): 3484(\mathrm{OH}), 1600$ and $1513(\mathrm{C}=\mathrm{C}$ aromatic $)$, 3000-2932 ( $\mathrm{C}_{\mathrm{sp} 3}-\mathrm{H}$ aliphatic), $1468\left(-\mathrm{CH}_{2}-\right), 1388\left(-\mathrm{CH}_{3}\right)$; ${ }^{1} \mathrm{H}-\mathrm{NMR}\left(300 \mathrm{MHz}, \mathrm{DMSO}-d_{6}\right) \delta(\mathrm{ppm}): 8.59(8 \mathrm{H}, \mathrm{m}, \mathrm{OH})$, 6.15-6.44 (16H, $m, \mathrm{ArH}), 5.45-5.71\left(4 \mathrm{H}, m, \mathrm{Ar}_{2} \mathrm{CHAr}\right), 4.65$ $\left(8 \mathrm{H}, d, \mathrm{ArCH}_{2} \mathrm{~N}-\right), \quad 3.65 \quad\left(24 \mathrm{H}, s, \mathrm{OCH}_{3}\right), \quad 1.10-2.90$ $\left(36 \mathrm{H}, m, \mathrm{NMe}_{3}\right) ;{ }^{13} \mathrm{C}-\mathrm{NMR}\left(75 \mathrm{MHz}\right.$, DMSO- $\left.d_{6}\right) \delta(\mathrm{ppm})$ :

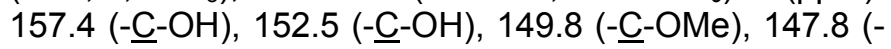
C-OMe), 134.4, 129.8, 124.6, 124.3, 121.3, 113.2, 108.8, $107.8(\mathrm{Ar}), 54.9\left(\mathrm{OCH}_{3}\right), 42.9,42.3,41.9\left(\mathrm{NMe}_{3}\right)$, $36.2\left(\mathrm{Ar}-\underline{\mathrm{C}} \mathrm{H}_{2}-\mathrm{NMe}_{2}\right), 31.1$ ( $\left.\mathrm{Ar}_{2} \underline{\mathrm{CHAr}}\right)$.

\section{Determination of oil-water partition coefficient}

Oil-water partition coefficients (log $\left.\mathrm{P}_{\mathrm{o} / \mathrm{w}}\right)$ was determined by solvent extraction method of the twophase, octanol as lipid and phosphate buffer solution as the aqueous phase, according to the previous procedure [27].

\section{Determination of acute toxicity $\left(L D_{50}\right)$}

Acute toxicity test $\left(L_{50}\right)$ of compound 3 was performed using mice with relatively similar weight, both males and females each divided into 5 groups of experimental animals. Four groups of mice were given orally with resorcinarene at different doses $(250,500$, 1000 , and $2000 \mathrm{mg} / \mathrm{kg}$ body weight), whereas the other group was a blank sample. $\mathrm{LD}_{50}$ was determined by counting the number of animal's deaths that occurred within $24 \mathrm{~h}$ to 20 days after the first administration of single doses.

\section{Antidote activity test}

Five groups of mice $(27 \pm 2 \mathrm{~g})$ were acclimated for 1 week before experimental use. They were allowed food and water ad libitum. Four groups of mice (each 6 mice) were injected with a solution of $\mathrm{K}_{2} \mathrm{Cr}_{2} \mathrm{O}_{7}$ orally at a dose of $0.12 \mathrm{mg}(120 \mathrm{ppm})$ every morning for 14 days. $\mathrm{LD}_{50}$ of $\mathrm{Cr}(\mathrm{Vl})$ is $3.43 \mathrm{mg} / \mathrm{kg}$ body weight [28]. Six hours later, the second, third, and fourth groups of mice were consecutively injected with the resorcinarene 3 orally at different doses $(25,50$, and $100 \mathrm{mg} / \mathrm{kg}$ body weight). The first group of mice was left without giving antidote as a negative control, while the fifth group was used as a blank sample. On day 29, after 2 week observation, the animals were sacrificed and the chromium content determined on samples of liver, kidney, and blood (serum), which had been digested in hydrochloric acid, using atomic adsorption spectrometry (AAS).

\section{RESULT AND DISCUSSION}

\section{Synthesis of Quaternary Ammonium Modified Resorcinarene}

In our previous work [1], reaction of resorcinol and 4-methoxybenzaldehyde in the presence of hydrochloric acid produce a cyclic tetramer of C-4-methoxyphenylcalix[4]resorcinarene. In the same way, then we introduce this method for a different starting material of aromatic aldehyde i.e. 4-hydroxy-3methoxybenzaldehyde. The synthesis of tetra and octafunctionalized calix[4]resorcinarene 1, 2, and 3 compounds using vanillin as an aromatic aldehyde through several stepwise reactions as shown in Fig. 1.

The ortho positions to hydroxyl groups at the resorcin residue are the most reactive and the most possible side on resorcinarene 1 toward electrophilic substitution such as Mannich reaction. The Mannich reaction involves the nucleophilic addition of a nucleophile to an iminium ion formed by the reaction of formaldehyde with a secondary amine [29-31]. In this research, synthesis of tetrakis-N,N-dimethylamino methyl-C-3,4-dimethoxyphenylcalix[4]resorcinarene (2) from compound 1 according to the Mannich procedure was carried out in the solvent of acetone at room temperature by using formaldehyde and dimethylamine in the presence of $\mathrm{HCl}$.

In this Mannich reaction, acid catalysts would protonize formaldehyde oxygen atom such that the carbon atom of formaldehyde is very reactive to being attacked by a lone pair of dimethylamine to form iminium ions which stabilized by resonance. The 


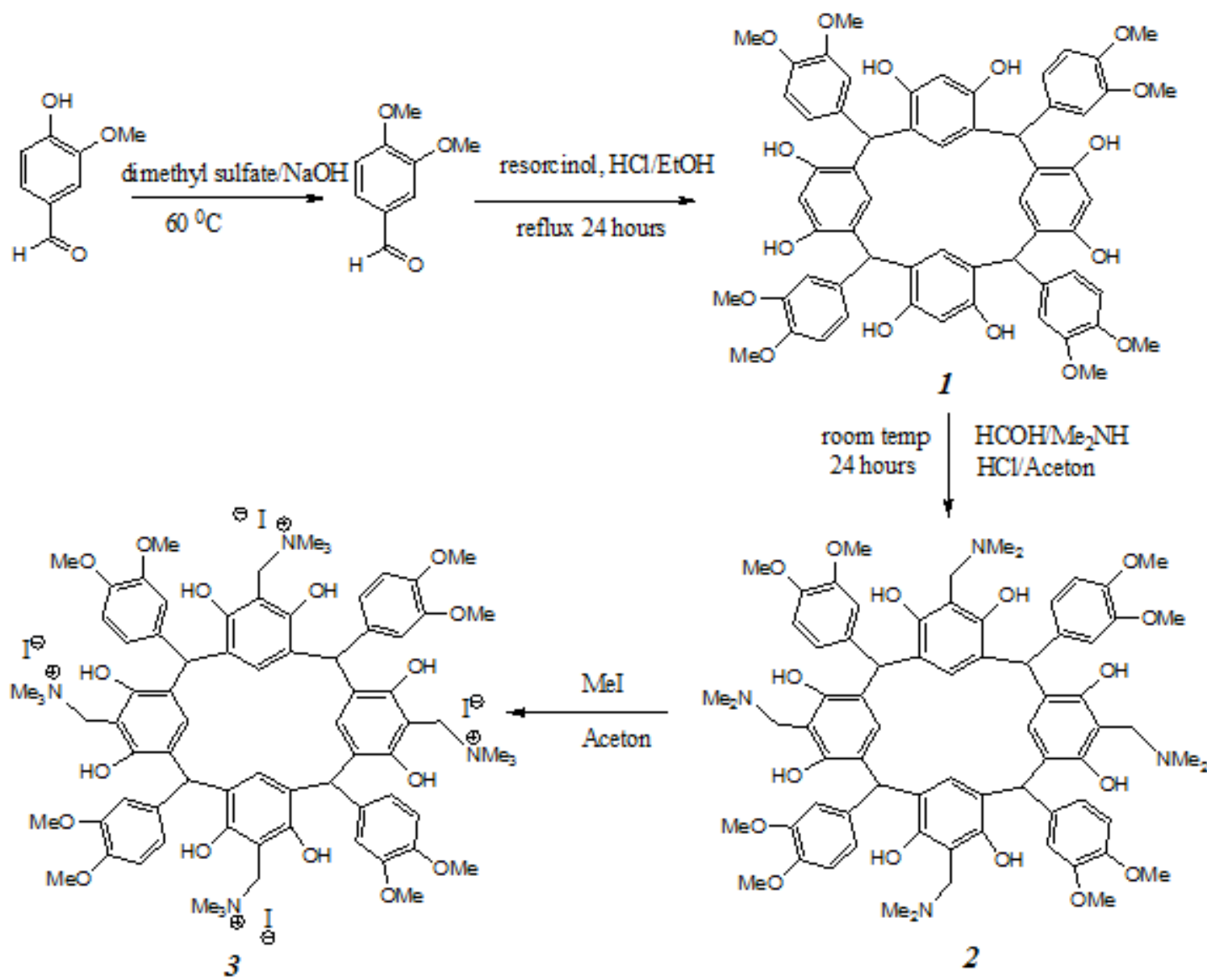

Fig 1. Overall stepwise reactions of resorcinarene 3 synthesis

existence of positive character iminium ion will push the electrophilic substitution reaction with the calix[4]resorcinarene 1. Iminium ions act as an electrophile agent. The number of iminium ion substitution on the compound 1 was proportional with the amount of iminium ion itself.

Resorcinarene 2 has 4 amine groups with certain basicity depend on the subtituent. Based on these properties, amine can undergo alkylation reactions with alkyl halides via a nucleophilic substitution reaction where the amine acts as a nucleophile while the alkyl halide acting as electrophile agent. Both of the primary, secondary, and tertiary amine can react with alkyl halides through nucleophilic substitution reaction. Even the tertiary amine competes with the ammonia to react with alkyl halides with the main product of ammonium salt. In this study, 4 active groups of the tertiary amine compound 2 will be further modified to quaternary ammonium groups. The existence of positive character of quaternary ammonium group on resorcinarene compound is expected to interact well with anionic species so that the final product modified quaternary ammonium will be effectively used as a host of heavy metal anion such as $\mathrm{Cr}_{2} \mathrm{O}_{7}{ }^{2-}$.

The modifying process of the tertiary amine group into quaternary ammonium on resorcinarene was done by reacting compound $\mathbf{2}$ with $\mathrm{Mel}$ in acetone at room temperature for $48 \mathrm{~h}$. Mel is the most powerful and reactive of primary alkyl halides when compared with other alkyl halides. The product of resorcinarene 3 was obtained as a light brown powder in $90.25 \%$ yield with melting point of $334-335^{\circ} \mathrm{C}$. The FTIR spectrum of this compound show many peaks consist of $\mathrm{OH}$ group (3484 $\left.\mathrm{cm}^{-1}\right), \mathrm{C}=\mathrm{C}$ aromatic $\left(1600\right.$ and $\left.1513 \mathrm{~cm}^{-1}\right)$, $-\mathrm{CH}_{2^{-}}\left(1468 \mathrm{~cm}^{-1}\right)$, and $-\mathrm{CH}_{3}\left(1388 \mathrm{~cm}^{-1}\right)$. Clear evidence of the quaternary ammonium salt was given by the ${ }^{1} \mathrm{H}-\mathrm{NMR}$ spectrum (Fig. 2) in which the presence of additional peaks at $\delta$ 1.1-2.9 ppm with total integration consist of 36 proton correspond to the $\mathrm{N}, \mathrm{N}, \mathrm{N}$-trimethylammonium iodide group $\left(-\mathrm{N}^{+}(\mathrm{Me})_{3} . \mathrm{I}^{-}\right)$.

The non-planarity of resorcinarenes means that they can, theoretically, exist in many different of isomeric forms. However, in the most cases, only two diastereoisomers were observed, those are crown and chair conformers [32-34]. Based on the proton NMR 


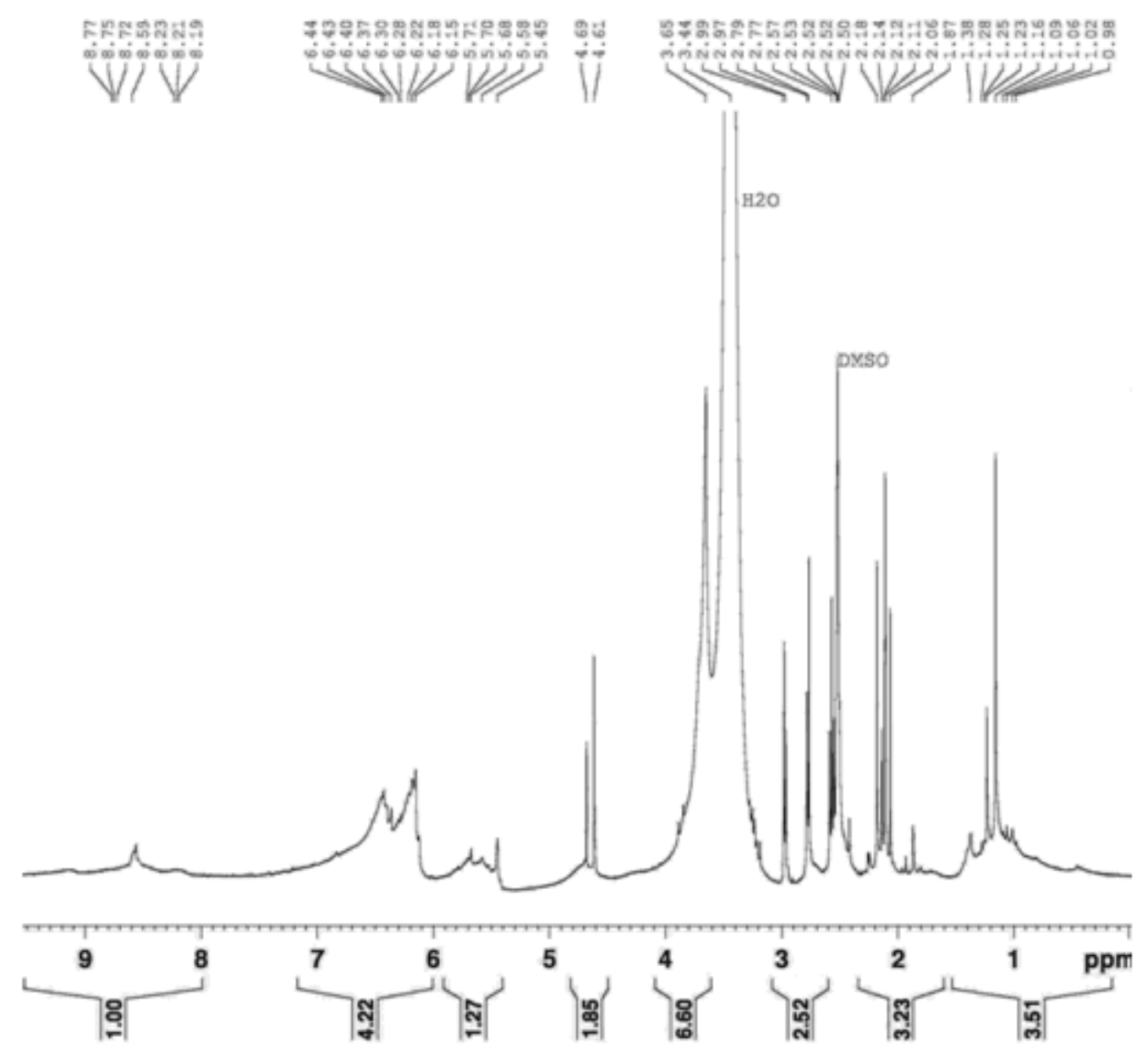

Fig 2. ${ }^{1} \mathrm{H}-\mathrm{NMR}$ spectrum of compound 3

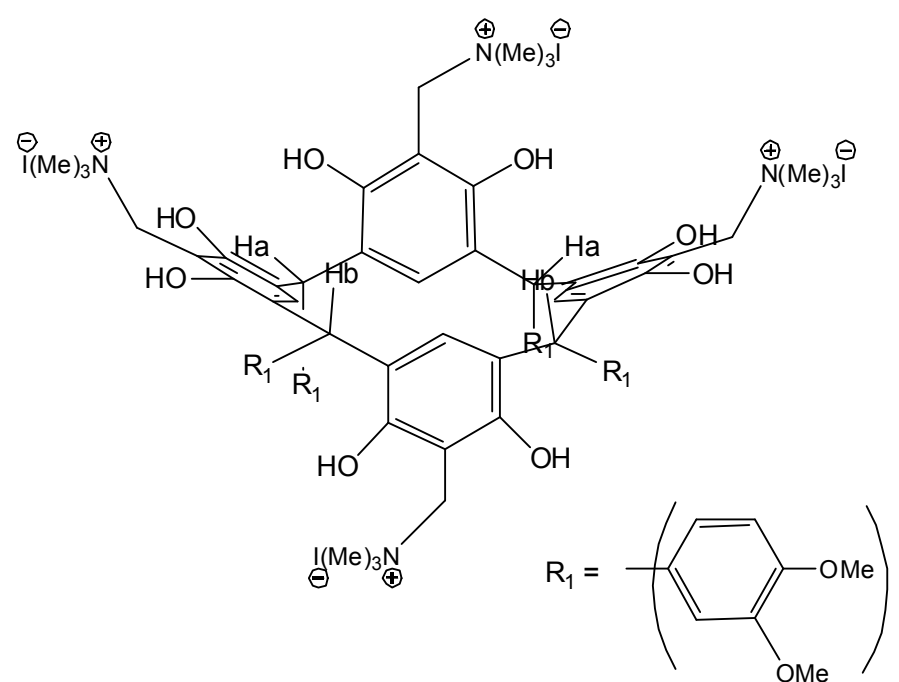

Fig 3. Conformation of resorcinarene 3

study (Fig. 2), the protons of methine groups of compound 3 provide multiple signal. This phenomena indicated that protons at methine bridge are decided in two direction namely equatorial $(\mathrm{Ha})$ and axial $(\mathrm{H} b)$ (Fig. 3). Therefore, the quaternary ammonium modified resorcinarene 3 exist in partial cone $(c c t)$ or chair $\left(\mathrm{C}_{2 h}\right)$ conformer. Further investigation to ArH protons signals show that there are multiple peaks too, thus the calix[4]resorcinarene prefer in the chair conformation.

\section{Partition Coefficient of Resorcinarene 3}

Partition coefficient describes the concentration of drug that dissolves in the fat phase (n-octanol) compared with the concentration of drug that dissolves in the aqueous phase (phosphate buffer). By knowing the value of the partition coefficient, we can indirectly know the amount of dissolved and adsorbed drug in target organs with certain properties. The exact method for determining the number of resorcinarene both in water and n-octanol was detected by a UV spectrophotometer. The results showed that resorcinarene 3 has a maximum wavelength of $212.2 \mathrm{~nm}$. Fat-water partition coefficient of compound 3 was evaluated at various $\mathrm{pH}$ by first making a curve of 


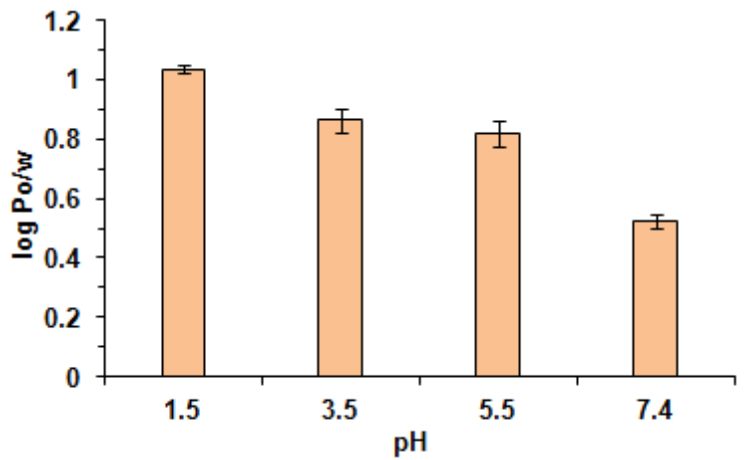

Fig 4. Oil-water partition coefficient of resorcinarene 3

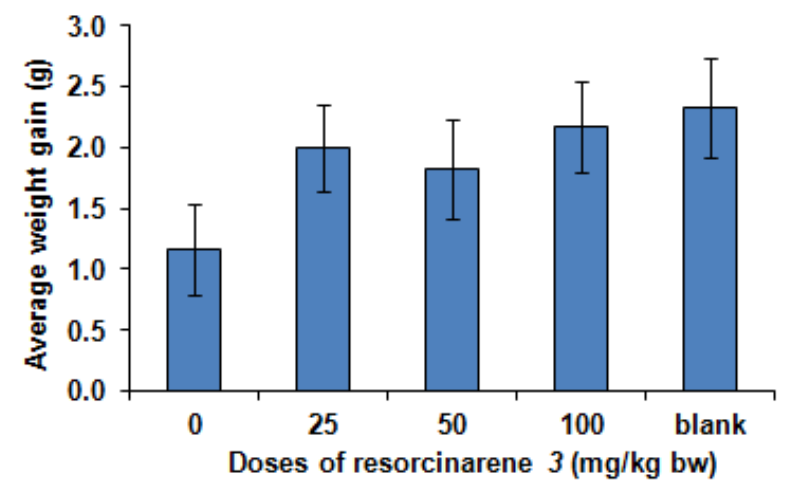

Fig 6. Influence of chromium intoxication and antidote doses on average weight gain

standard solutions at pH 1.5, 3.5, 5.5, and 7.4 (Fig. 4).

A compound which is soluble in the two solvents that do not interfere with each other then the compound will be distributed into the polar phase (water) and nonpolar phase (octanol, chloroform, etc.). After equilibrium level was reached, compound in both solvents always fixed (at a constant temperature) so that the partition coefficient value can be determined. In this study, the optimum incubation time is determined when the decreasing of resorcinarene $\mathbf{3}$ concentration in n-octanol phase relatively constant, the achievement equilibrium was gained.

The result of the fat-water partition coefficient determination of 3 was presented in Fig. 4. Fat-water partition coefficient of the compound has different values at each $\mathrm{pH}$ experiment. Based on Fig. 4 showed the greater $\mathrm{pH}$ of phosphate buffer solution cause the smaller of $\log \mathrm{P}_{\mathrm{o} / \mathrm{w}}$. This indicate that the degree of lipophilicity of the compound decrease with increasing $\mathrm{pH}$.

In general, the results of fat-water partition coefficient determination (Fig. 4) showed the value of log $\mathrm{P}_{\mathrm{o} / \mathrm{w}}$ were between 0.52 to 1.03 at $\mathrm{pH}$ region of 1.5 to 7.4. At $\mathrm{pH} 1.54$ the value of $\log \mathrm{P}_{\mathrm{o} / \mathrm{w}}$ of resorcinarene 3 was more than 1 , which means that the value of $P>10$. This suggests that more than 10 parts of the compound are in the organic layer and less than 1 part in water

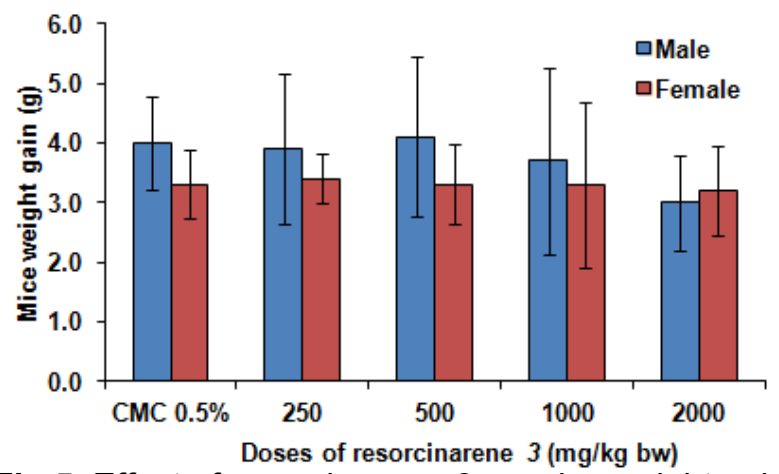

Fig 5. Effect of resorcinarene $\mathbf{3}$ on mice weight gain

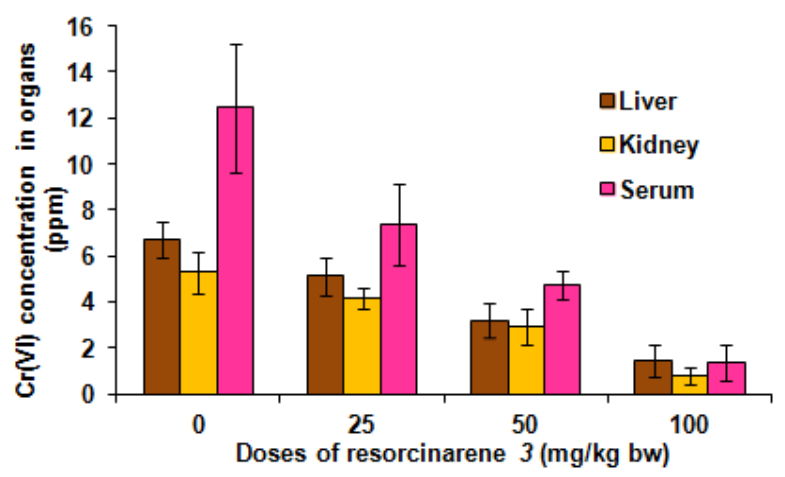

Fig 7. Effect of chromium intoxication and antidote dose on $\mathrm{Cr}(\mathrm{VI})$ concentration in organs

phase. Thus lipophilicity of resorcinarene 3 is high enough so that it can penetrate through non-polar site of biological membranes. The value of $\log \mathrm{P}_{\mathrm{o} / \mathrm{w}}$ at $\mathrm{pH}$ $3.5,5.5$ and 7.4 were gradually decreased to 0.5 . This gives another advantage of resorcinarene 3 to be more easily excreted or released from the body's biological system after binding the toxin target.

\section{The Toxicity of the Drug}

Determination of $\mathrm{LD}_{50}$ was conducted to examine the relationship of resorcinarene dose with toxic effects. This test is designed to measure the degree of toxic effects of a compound that occurs in a short time, i.e. $24 \mathrm{~h}$ after administration in a single dose. From the results of the study, no one of mice died after treatment. Even in the observation period of up to 3 weeks after injection of a single dose of $2000 \mathrm{mg} / \mathrm{kg}$ of the drug, there is no animal that showed clinical symptoms (toxic effects) and lead to death. Therefore, the resorcinarene $\mathbf{3}$ was classified as non toxic compound according to Loomis criteria [35].

The low degree of toxicity of the compound was also supported by data from animal weight measurements of both males and females in different doses as shown in Fig. 5. Based on the chart, there was no significant weight gain differences $(P>0.05)$ 
between the control group (CMC 0.5\%) and groups given orally at various drug doses. This indicate that the presence of resorcinarene 3 in the body, although it has active side of a positive character, but does not interfere with the interaction between essential metal ions $(\mathrm{Mg}$, $\mathrm{Ca}, \mathrm{K})$ with physiologic ligands such as hydroxyl $(-\mathrm{OH})$, carboxyl $\left(\mathrm{RCOO}^{-}\right)$, phosphates $\left(\mathrm{HPO}_{4}^{-}\right)$, carbonyl $(\mathrm{C}=\mathrm{O})$, thiol $(-\mathrm{SH})$ and amine $\left(-\mathrm{NH}_{2}\right)$ groups. Thus the processes of essential metals absorption occur continuously to pose no metallic mineral deficit (anemia) and weight loss.

\section{Antidote Activity Test}

Based on observations of animal body weight (Fig. 6), control group of mice (I) with only $\mathrm{Cr}(\mathrm{VI})$ administration without any further treatment showed the lowest weight gain compared with the positive control group (blank) and groups given antidote in various doses $(25,50$, and $100 \mathrm{mg} / \mathrm{kg} \mathrm{bw})$. This indicates that the presence of $\mathrm{Cr}(\mathrm{VI})$ in mice physically may cause interference or inhibition of the development of body weight. The mechanism of the weight gain disorder comes from the direct toxic activity of chromium in the tissue. The existence of $\mathrm{Cr}(\mathrm{VI})$ in the body will alter hormonal metabolism and reduced absorption of essential metals causing anemia and weight loss [22]. The result also showed that compound 3 affect the activity of $\mathrm{Cr}(\mathrm{VI})$ and reduce the negative impacts that are detected by normally weight gain.

Symptoms of $\mathrm{Cr}(\mathrm{VI})$ poisoning is also common on the weight disorder of vital organs of excretion involving the liver and kidneys. Based on previous studies on the toxicology of $\mathrm{Cr}(\mathrm{VI})$ stated that hexavalent chromium able to induce tissue damage. Recent studies also indicate the presence of lesions in the kidney tissue [22] after experimental animals were given food containing $\mathrm{Cr}(\mathrm{VI})$.

Therapy using resorcinarene 3 (Fig. 7) prevent and reduce metal concentrations accumulated in organs. The higher doses of drug administered the greater decrease in the levels of heavy metals. At the highest dose (100 $\mathrm{mg} / \mathrm{kg} \mathrm{bw}$ ), reduction of the total chromium concentration in the liver, kidney, and serum was $78.30,85.72$ and $88.79 \%$ respectively. In the terms of the amount of milligrams (chromium) per gram of organ, the kidney was the highest on decreasing metal concentration. In general, the excretion of chromium was done mainly by the kidney and liver, as well as in smaller amounts in the bile, milk and hair. It shows that more chromium residues accumulate in the kidney than in liver. This fact corresponds to the results of investigations using radioactive ${ }^{51} \mathrm{Cr}$ which proves that chromium deposited up to 6 times in kidney than liver and blood [22].

\section{CONCLUSION}

Tetrakis-N,N,N-trimethylammoniummethyl-C-3,4dimethoxyphenylcalix[4]resorcinarene iodide (3) has been synthesized via Mannich reaction of tetrakis-N,Ndimethylaminomethyl-C-3,4-

dimethoxyphenylcalix[4]resorcinarene (2) followed by alkylation with Mel. Resorcinarene $\mathbf{3}$ has enough solubility in fat but lower in water except in alkaline $\mathrm{pH}$. It means that the resorcinarene can penetrate to the cell membrane thus it still be able to contribute on binding with chromium in the liver and kidney. Treatment using resorcinarene $\mathbf{3}$ prevent and reduce metal concentrations accumulated in organs. The higher doses of drug administered the greater decrease in the levels of heavy metals.

\section{ACKNOWLEDGEMENT}

The authors gratefully acknowledge to the Directorate General of Higher Education, Republic of Indonesia, for financial support through the research grant program on 2013/2014.

\section{REFERENCES}

1. Utomo, S.B., Jumina, Siswanta, D., Mustofa, and Kumar, N., 2011, Indo. J. Chem., 11, 1, 1-8

2. Jumina, Sarjono, R.E., Paramita, B.W., Siswanta, D., Santosa, S.J., Anwar, C., Sastrohamidjojo, H., Ohto, K., and Oshima, T., 2007, J. Chin. Chem. Soc., 54, 5, 1167-1178.

3. Aoyoma, Y., Tanaka, Y., and Sugahara, S., 1989, J. Am. Chem. Soc., 111, 14, 5397-5404.

4. Boas, U., and Heegaard, P.M., 2004, Chem. Soc. Rev., 33, 1, 43-63.

5. Tunstand, L.M., Tucker, J.A., Dalcanale, E., Weiser, J., Bryant, J.A., Sherman, J.C., Helgeson, R.C., Knobler, C.B., and Cram, D.J., 1989, J. Org. Chem., 54, 6, 1305-1312.

6. Arora, V., Chawla, H.M., and Singh, S.P., 2007, Arkivoc, 2, 172-200.

7. Fox, O.D., Cookson, J., Wilkinson, E.J.S., Drew, M.G.B., MacLean, E.J., Teat, S.J., and Beer, P.D., 2006, J. Am. Chem. Soc., 128, 21, 6990-7002.

8. Utomo, S.B., Jumina, Siswanta, D., and Mustofa, 2012, Indo. J. Chem., 12, 1, 49-56.

9. Utomo, S.B., Jumina, and Wahyuningsih, T.D., 2009, Indo. J. Chem., 9, 3, 437-444.

10. Moore, S.S., Tarnowski, T.L., Newcomb, M., and Cram, D.J., 1977, J. Am. Chem. Soc., 99, 19, 6398-6405.

11. Zhao, J., Bolte, M., Dordea, C., Gruner, B., and Bohmer, V., 2009, Synthesis, 23, 4063-4067. 
12. Kalenius, E., Kekäläinen, T., Neitola, R., Beyeh, K., Rissanen, K., and Vainiotalo, P., 2008, Chem. Eur. J., 14, 17, 5220-5228.

13. Henge-Napoli, M.H., Archimbaud, M., Ansoborlo, E., Metivier, H., and Gourmelon, P., 1995, Int. J. Radiat. Biol., 68, 4, 389-393.

14. Shinkai, S., Mori, S., Koreishi, H., Tsubaki, T., and Manabe, O., 1986, J. Am. Chem. Soc., 108, 9, 2409-2416.

15. Yang, W., and Villiers, M.M., 2005, AAPS J., 7, 1, 241-248.

16. Widianarko, B., Verweij, R.A., van Gestel, C.A., and van Straalen, N.M., 2000, Ecotoxicol. Environ. Saf., 46, 1, 95-100.

17. Hartono and Santosa, E.B., 2005, Enviro, 6, 2, 5863.

18. Abidin, Z., and Sunardi, 2009, Indo. J. Chem., 9, 3, 425-431.

19. William, P.L. and James, R.C., 2000, Principles of Toxicology, $2^{\text {nd }}$ ed., John Wiley and Sons, New York.

20. Hansen, M.B., Johansen, J.D., and Menné, T., 2003, Contact Dermatitis, 49, 4, 206-212.

21. Vasant, C., Rajaram, R., and Ramasami, T., 2003, Free Radical Biol. Med., 35, 9, 1082-1100.

22. Silva, R.C., Júnior, J.C.R., Varaschin, M.S., de Sousa, R.V., Oliveira, L.C.A., Daniel, J.L.P., de Lima, R.F., and Moreiva, A.O., 2010, Anim. Prod. Sci., 50, 4, 293-299.

23. Wedeen, R.P., and Qian, L.F., 1991, Environ. Health Perspect., 92, 71-74.
24. Dartsch, P.C., Hildenbrand, S., Kimmel, R., and Schmahl, F.W., 1998, Int. Arch. Occup. Environ. Health, 71, S40-S45.

25. Kirpnick-Sobol, Z., Reliene, R, and Schiestl, R.H., 2006, Cancer Res., 66, 7, 3480-3484.

26. Jumina, Rastuti, U., and Matsjeh, S., 2003, Indo. J. Chem., 3, 1, 14-18

27. Sangster, J., 1997, Octanol-Water Partition Coefficients: Fundamentals and Physical Chemistry, Vol. 2 of Wiley Series in Solution Chemistry, John Wiley \& Sons, New York.

28. Jacob, A.J., Guertin, J., and Avakian, C., 2005, Chromium (VI) Handbook, CRC Press, New York

29. Suginome, M., Uehlin, L., and Murakami, M., 2004, J. Am. Chem. Soc., 126, 41, 13196-13197.

30. Matsuo, J.I., Tanaki, Y., and Ishibashi, H., 2006, Org. Lett., 8, 4371-4374.

31. Song, J., Shih, H.-W., and Deng, L., 2007, Org. Lett., 9, 603-606.

32. Högberg, A.G.S., 1980, J. Am. Chem. Soc., 102, 19, 6046-6050.

33. Erdtman, H., Högberg, S., Abrahamsson, S., and Nilsson, B., 1968, Tetrahedron Lett., 9, 14, 16791682.

34. Gutsche, C.D., 1989, Calixarenes. Monograph in Supramolecular Chemistry, Royal Society of Chemistry, Cambridge.

35. Loomis, T.A., and Hayes, A.W., 1996, Loomis's Essentials of Toxicology, $4^{\text {th }}$ ed., Academic press, California. 